\title{
SCREENING OF HETEROCYCLIC SUBSTITUTED SYDNONES FOR POTENTIAL BIOLOGICAL ACTIVITY
}

\author{
NICOLETA OLGUTA CORNELI ${ }^{1}$, FLORIN ALBOTA ${ }^{2}$, CRISTIANA CERASELLA \\ DRAGOMIRESCU ${ }^{1,3}$, MICHAELA DINA STANESCU $^{4 *}$ \\ 1 "Cantacuzino” National Institute of Research, 103 Splaiul Independentei, 050096, Bucharest, Romania \\ 2 “C. D. Nenițescu” Centre of Organic Chemistry, 202 Splaiul Independenței, 060021 Bucharest, Romania \\ 3 "Carol Davila” University of Medicine and Pharmacy, 37 Dionisie Lupu Street, 020021 Bucharest, Romania \\ 4 “C. D. Nenitescu” Department of Organic Chemistry, Faculty of Applied Chemistry and Material Science, POLITEHNICA \\ University, 1-7 Polizu Street, 011061, Bucharest, Romania
}

*corresponding author: michaela.stanescu@chimie.upb.ro

Manuscript received: January 2018

\begin{abstract}
Nowadays, the emergence of bacterial resistance to antibiotics has become a major public health concern; therefore the development of new compounds overcoming the bacterial resistance is essential. Thus, this study evaluates the in vitro antimicrobial activity of some recently synthesized sydnone derivatives, on Gram-positive (Staphylococcus aureus, Bacillus subtilis), Gram-negative (Klebsiella pneumoniae, Escherichia coli, Pseudomonas aeruginosa) bacteria and fungi (Candida albicans, Aspergillus niger) and estimates the influence of sub-inhibitory concentrations of these newly synthesized compounds on the expression of some virulence factors by bacterial strains and on adhesion ability to inert substrates.
\end{abstract}

\section{Rezumat}

În prezent, apariția rezistenței bacteriene la antibiotice a devenit o problemă majoră de sănătate publică, prin urmare dezvoltarea de antibiotice noi este esențială. Acest studiu evaluează activitatea antimicrobiană in vitro a unor sydnone sintetizate recent, folosind bacterii Gram-pozitive (Staphylococcus aureus, Bacillus subtilis) și Gram-negative (Klebsiella pneumoniae, Escherichia coli, Pseudomonas aeruginosa), dar și fungi (Candida albicans, Aspergillus niger) și determină influența concentrațiilor subinhibitoare a acestor compuși nou sintetizați asupra exprimării unor factori de virulență la tulpinile bacteriene şi asupra aderenţei bacteriene.

Keywords: sydnone derivatives, antimicrobial activity, virulence factors expression, inhibition of microbial adherence

\section{Introduction}

Sydnones, heterocyclic compounds with mesoionic structure, have been synthesized the first time in 1935 [12]. Compounds belonging to this class have been studied in the laboratories of the Centre of Organic Chemistry since 1965 [17], their structure and properties being of continuous interest, fact reflected in a number of published papers, some of them being mentioned here [9-11]. The sydnones are interesting because these compounds revealed a variety of biological activities like: antimicrobial, antifungal, antihelmintic, antiinflamatory or analgesic [1]. Recently a number of heterocyclic substituted sydnones (1-6) (as presented in Table I) have been prepared and their structure was confirmed by spectral analyses (IR, UV-Vis, NMR and X-ray) [2, 3]. In the view of finding new compounds having antibacterial or antifungic activity, this paper presents the evaluation of the effects of these recently synthesized sydnones on bacterial and fungal strains.

\section{Materials and Methods}

The structures of the sydnone derivatives 1-6 [2] are presented in Table I. Stock solutions of $1 \mathrm{mg} / \mathrm{mL}$, prepared by dissolving the test compounds 1-6 in sterile dimethyl sulphoxide (DMSO), were stored at $4^{\circ} \mathrm{C}$.

The antimicrobial properties of these compounds were tested against reference strains from the "Cantacuzino" Institute Collection (IC), Bucharest, Romania: Staphylococcus aureus (S. aureus) IC 13204, Bacillus subtilis (B. subtilis) IC 12488, Escherichia coli (E. coli) IC 13529, Klebsiella pneumoniae (K. pneumoniae) IC 13420, Pseudomonas aeruginosa ( $P$. aeruginosa) IC 13202, Candida albicans (C. albicans) IC 249, Aspergillus niger (A. niger) IC 13534 and, also, against bacteria strains recently isolated from clinical infections: P. aeruginosa $211349, P$. aeruginosa, E. coli 211602, E. coli 211850, K. pneumoniae 211790, K. pneumoniae $210703, K$. pneumoniae 63 . The bacterial strains were identified with VITEK 2 System Version 07.01. The VITEK cards for identification 
were inoculated and incubated as previously described [15].

The microbial inocula were prepared in sterile saline solution from 18 - $24 \mathrm{~h}$ microbial cultures (4 - 5 isolated colonies) developed on solid media and adjusted by nephelometry to a standard density $0.5 \mathrm{McF}$ arland (corresponding to $1.5 \times 10^{8} \mathrm{CFU} / \mathrm{mL}$ for bacteria and $5 \times 10^{6} \mathrm{CFU} / \mathrm{mL}$ for fungi). For $A$. niger a sporal suspension with $0.5 \mathrm{McF}$ arland density was used $[5,6]$.

The qualitative screening of the antimicrobial properties for compounds 1-6 was performed by a procedure adapted from Kirby-Bauer diffusion method. Petri dishes with nutrient media: Mueller Hinton agar, for bacterial strains and Yeast Extract-PeptoneGlycerol (YPG) for fungal strains, were seeded with bacterial/fungal inocula of $0.5 \mathrm{McFarland}$ optical densities, then $10 \mu \mathrm{L}$ of the compounds 1-6 solutions were added in spots. The Petri dishes were left at room temperature to allow a drop of solution to be adsorbed in the medium and afterwards they were incubated at $37^{\circ} \mathrm{C}$ during $24 \mathrm{~h}$ for bacteria and $48 \mathrm{~h}$ for fungi. The DMSO solvent was also tested to evaluate its potential antimicrobial activity. The bactericidal/fungicidal effect was observed by the occurrence of a growth inhibition zone around the spots. The results were expressed as diameters of the inhibition zones generated by the tested compounds [5].

Quantitative assays, for establishing the minimal inhibitory concentration (MIC), were performed by the binary microdilution method, in 96-well plates. Binary serial dilutions of the stock solutions were prepared in $150 \mu \mathrm{L}$ medium, after which the wells were seeded with $10 \mu \mathrm{L}$ of microbial suspension of $0.5 \mathrm{McF}$ arland density values, $1: 10$ diluted. The plates were incubated at $37^{\circ} \mathrm{C}$ for $24 \mathrm{~h}$ for bacteria and $48 \mathrm{~h}$ for fungi. For each test, a microbial culture control and a sterility control were performed. DMSO was also tested by binary serial dilution to evaluate its potential antimicrobial activity [8]. The reference substances used were: ciprofloxacin (CIP) a fluoroquinolone antibiotic for bacterial strains and fluconazole (FLU) a triazole derivative for fungal strains, each as a $128 \mu \mathrm{g} / \mathrm{mL}$ solution. MICs were read by the wells observation. The MICs values were confirmed by absorbance measurement at $620 \mathrm{~nm}[5,6]$. For investigating the influence of the tested compounds on the expression of different virulence factors, bacterial strains were cultivated in the presence of sub-inhibitory concentrations of compounds 1-6. Then, $10 \mu \mathrm{L}$ of each bacterial culture were inoculated in spots on specific media, simultaneously with control samples, to determine the expression of the virulence factors [7]. $\beta$-Haemolysin was evidenced by spotting strains on blood agar plates containing $5 \%(\mathrm{v} / \mathrm{v})$ sheep blood. After incubation at $37^{\circ} \mathrm{C}$ for $24 \mathrm{~h}$, the clear areas (total lysis of the red blood cells) around the colonies point out a positive reaction. For the caseinase activity, the strains were spotted on $10 \%$ soluble casein agar as substrate. After incubation at $37^{\circ} \mathrm{C}$ for $24 \mathrm{~h}$, a precipitation zone surrounding the bacteria growth indicated the casein production. For the lecithinase production, the cultures were spotted into $8 \%$ eggs yolk agar and were incubated at $37^{\circ} \mathrm{C}$ for 7 days. An opaque (precipitation) zone around the spot indicates the lecithinase production. For the investigation of lipase production, the strains were spotted on Tween 80 (oleic acid ester) with agar as a substrate, at a final concentration of $0.5 \%$ and the plates were incubated at $37^{\circ} \mathrm{C}$ for 7 days. An opaque (precipitation) zone around the spot was registered as a positive reaction $[4,13]$.

To study the susceptibility of compounds 1-6 to inhibit biofilm formation, an experimental model was developed. Thus, after the MIC assay, the liquid cultures from the 96-well plates were removed and the wells were washed three times with phosphate buffer saline (PBS), fixed with methanol for 5 minutes, stained with $1 \%$ violet crystal solution for 30 minutes, washed with distilled water and dissolved in $33 \%$ acetic acid, and thereafter, the adhesion ability to the abiotic surface was determined by reading the coloured suspension density to an Elisa reader at $490 \mathrm{~nm}[16]$.

\section{Results and Discussion}

Six recently synthesized compounds with a sydnone moiety [2] have been tested, in vitro, against pathogenic bacteria and fungi. Table I contains the structures and some spectral data of these compounds. 
The chemical structure of the tested sydnones

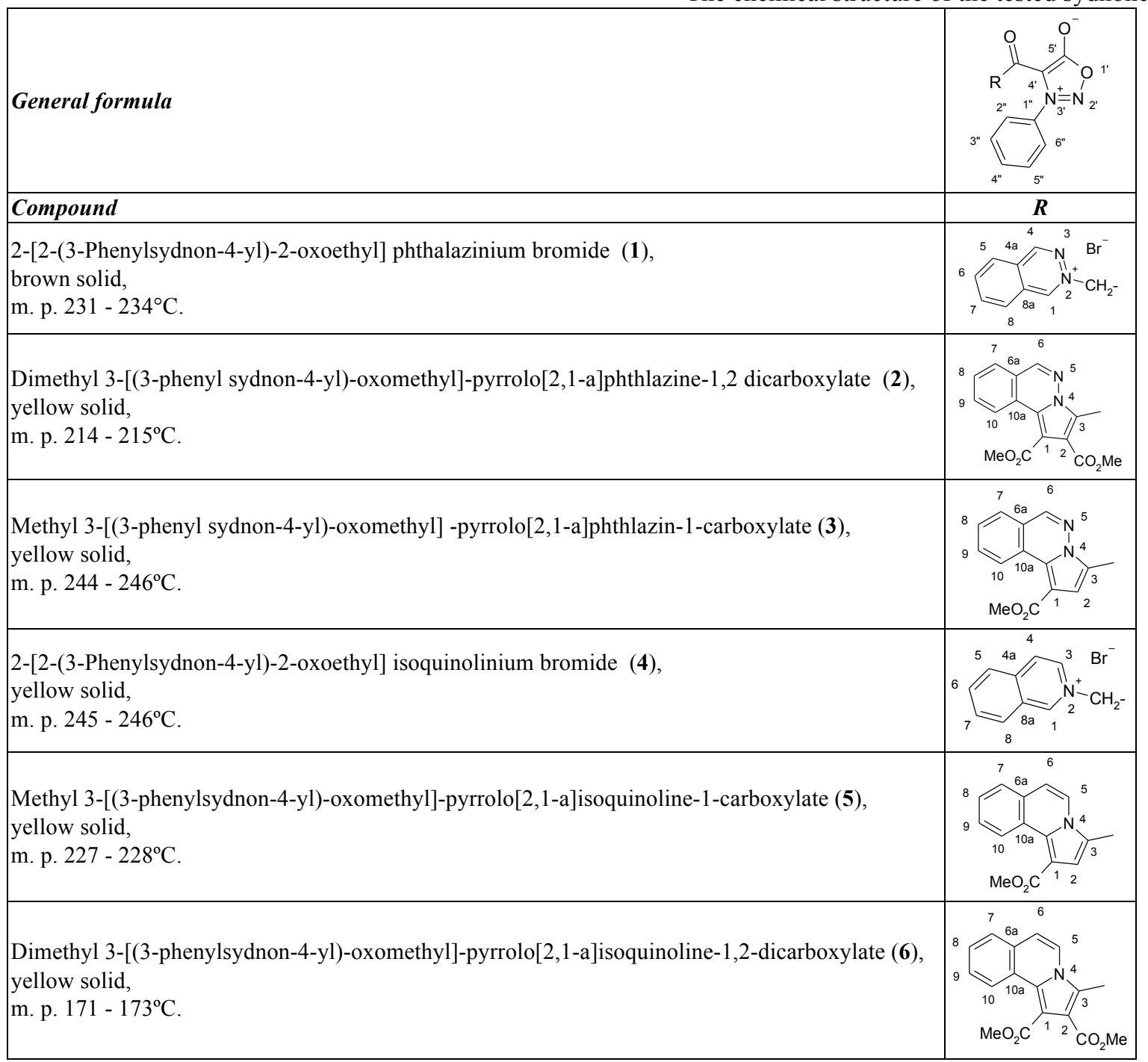

The results obtained from the qualitative tests showed an antimicrobial activity of compound $\mathbf{4}$ on both Gram-positive bacteria species $(\mathrm{d}=8-10 \mathrm{~mm})$, and Gram-negative bacteria species $(\mathrm{d}=5-6 \mathrm{~mm})$. For the other compounds there is no evidence of inhibition zones around the spots $(\mathrm{d} \sim 0 \mathrm{~mm})$. The DMSO has no effect on the checked microorganisms. The results of the quantitative assay of the antimicrobial activity against reference strains showed that compound $\mathbf{4}$ exhibited the highest activity against $E$. coli (MIC of $62.5 \mu \mathrm{g} / \mathrm{mL}$ ), similar action against $P$. aeruginosa, $K$. pneumonia, $S$. aureus and A. niger (MIC of $125 \mu \mathrm{g} / \mathrm{mL}$ ) and lower inhibitory effect on B. subtilis and C. albicans (MIC of 250 $500 \mu \mathrm{g} / \mathrm{mL}$ ) (Table II). In the case of clinically isolated Gram-negative strains, an antimicrobial activity was observed with $\mathrm{MIC}=250 \mu \mathrm{g} / \mathrm{mL}$, only on the $E$. coli strains (E. coli 211602 and E. coli 211850).

Table II

The results of the antimicrobial activity (MIC values in $\mu \mathrm{g} / \mathrm{mL}$ )

\begin{tabular}{|l|c|c|c|c|c|c|c|c|}
\hline \multirow{2}{*}{ Microbial strains } & \multicolumn{9}{|c|}{ MIC $(\mu \mathrm{g} / \mathrm{mL})$} & $\mathbf{5}$ & $\mathbf{6}$ & CIP & FLU \\
\cline { 2 - 9 } & $\mathbf{1}$ & $\mathbf{2}$ & $\mathbf{3}$ & $\mathbf{4}$ & $\mathbf{5}$ & $\mathbf{2}$ & - \\
\hline P. aeruginosa IC 13202 & 500 & 500 & 500 & 125 & $>500$ & $>500$ & 0.25 & - \\
\hline E. coli IC 13529 & 500 & 500 & $>500$ & 62,5 & $>500$ & $>500$ & $<0.125$ & - \\
\hline K. pneumoniae IC 13420 & 500 & 500 & $>500$ & 125 & $>500$ & $>500$ & $<0.125$ & - \\
\hline S. aureus IC 13204 & 500 & 500 & $>500$ & 125 & $>500$ & $>500$ & 0.25 & - \\
\hline B. subtilis IC 12488 & $>500$ & $>500$ & $>500$ & 500 & $>500$ & $>500$ & 0.25 & - \\
\hline C. albicans IC 249 & $>500$ & $>500$ & $>500$ & 250 & $>500$ & $>500$ & - & 15.62 \\
\hline A. niger IC 13534 & 500 & 125 & 500 & 125 & 500 & 500 & - & 15.62 \\
\hline
\end{tabular}


FARMACIA, 2018, Vol. 66, 4

According to the experimental results, compounds 1-6 have no influence on the secretion of soluble bacterial virulence factors ( $\beta$-haemolysin, caseinase, lecithinase, lipase) implicated in the infectious process progression.

The notion of adherence in biology is an important concept, because fixation mechanisms represent the stage preceding the onset of an infectious process. The bacterial adhesion at the host tissues or the prosthetic medical devices, determinate morphological and behavioural changes in bacterial cells, leading to the development of biofilms conferring high resistance to the antibiotic therapy [14].
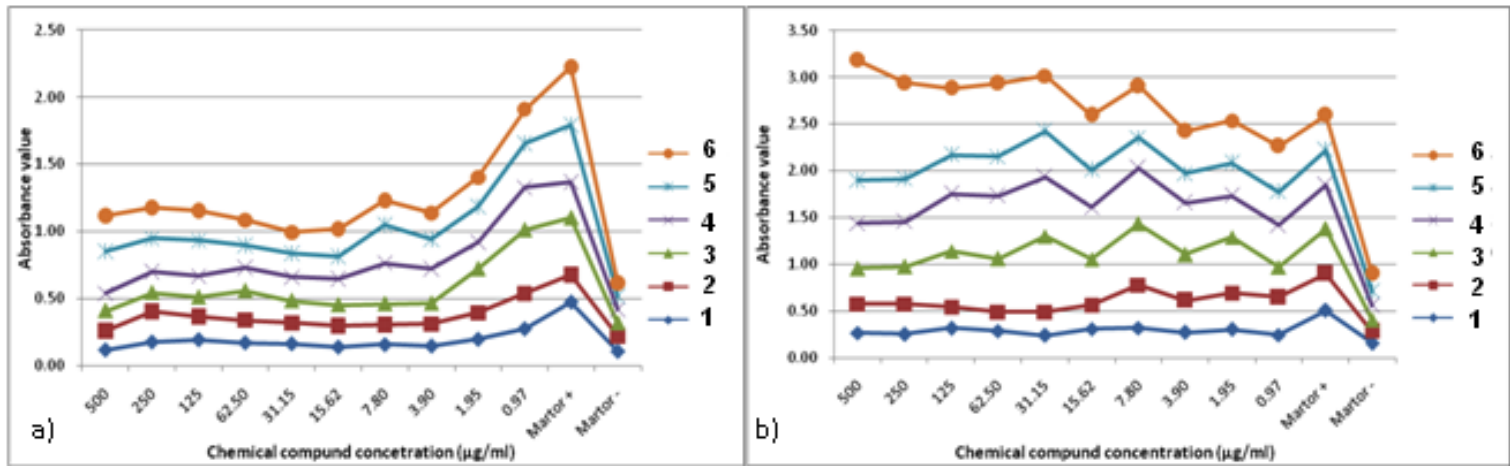

Figure 1.

The influence of sub-inhibitory concentrations of compounds 1-6 upon bacterial adherence on an inert substrate: a) P. aeruginosa IC 13202; b) B. subtilis IC 12488

It was observed that the sub-inhibitory concentration of almost all compounds tested caused an inhibition of adhesion ability to inert substrates of the Gramnegative reference bacterial strains. Exceptions are compounds $\mathbf{5}$ and $\mathbf{6}$, which caused a slight stimulation of adherence to the inert substrate for $E$. coli IC 13529. It could be hypothetically explained by the stimulation of the bacterial adhesins expression, causing colonization and biofilm formation. In the case of Gram-positive bacteria significant changes were not observed in the adherence ability to the inert substrate, except for the compound $\mathbf{6}$ which determined stimulation of the adherence to the inert substrate of B. subtilis IC 12488. For clinically isolated strains it was noticed that compound $\mathbf{4}$ caused an inhibition of adhesion ability to the inert substrate (Figure 1).

\section{Conclusions}

According to the experimental results, the isoquinoline sydnone derivative $\mathbf{4}$ shows a potential antimicrobial activity. Starting from this compound, further structureactivity relationship and molecular docking studies have to be performed for designing and synthesizing new molecules with better antimicrobial activity and higher efficiency in bacterial biofilm destruction.

\section{References}

1. Albota F, Stanescu MD, The state of art in sydnones chemistry and applications. Rev Roum Chim., 2017; 62(10): 711-734.

2. Albota F, Drăghici C, Caira MR, Dumitrascu F, 1,3Dipolar cycloaddition between acetylenic dipolarophiles and sydnone-N-ylides as bis(1,3-dipoles). Tetrahedron, 2015; 71: 9095-9100.

3. Albota F, Tociu M, Stanescu MD, Dumitrascu F, Influence of the substituents on the spectral data of sydnones. U.P.B. Sci. Bull., Series B, 2016; 78(4): 101-108.

4. Bădiceanu CD, Nuță DC, Missir AV, Hrubaru M, Delcaru C, Dițu LM, Chifiriuc MC, Limban C, Synthesis, structural, phisico-chemical characterization and antimicrobial activity screening of new thiourea derivatives. Farmacia, 2018; 66(1): 149-156.

5. Clinical and Laboratory Standards Institute, Performance Standards for Antimicrobial Susceptibility Testing, $24^{\text {th }}$ ed., Informational Supplement M100-S24, Wayne, PA, 2014; 34(1).

6. Clinical and Laboratory Standards Institute, Reference method for broth dilution antifungal susceptibility testing of yeasts, $3^{\text {rd }}$ ed., Approved standard M27 A3, Wayne, PA, 2008.

7. Delcaru C, Chifiriuc MC, Dracea O, Carmen I, Limban C, Nitulescu GM, Missir AV, Chirita IC, Badiceanu $\mathrm{C}$, Bleotu C, Sakizlian R, Israil AM, In vitro evaluation of the influence of compounds with tricyclic structure on the microbial growth and expression of virulence factors. Afr J Pharm Pharmacol., 2012; 6(23): 1631-1638.

8. Drăcea $\mathrm{O}$, Larion $\mathrm{C}$, Chifiriuc $\mathrm{MC}$, Raut I, Limban C, Nițulescu GM, Bădiceanu CD, Israil AM, New thioureides of 2-(4-methylphenoxymethyl) benzoic acid with antimicrobial activity. Rom Arch Microbiol Immunol., 2009; 67(3-4): 92-97.

9. Dumitraşcu F, Drăghici C, Dumitrescu D, Tarko L, Răileanu D, Direct Iodination of Sydnones and Their Cyclo-additions to Form 5-Iodopyrazoles. Liebigs Ann Requil., 1997; 12: 2613-2616.

10. Dumitraşcu F, Mitan CI, Dumitrescu D, Drăghici C, Căproiu MT, Steric effects on the sydnones 
reactivity. New sydnones and pyrazoles. Arkivoc, 2002; ii: 80-86.

11. Dumitraşcu F, Drăghici C, Vuluga D, Căproiu MT, New pyrazoles by 1, 3-dipolar cycloaddition reactions between sydnones and activated alkynes. Rev Roum Chim., 2006; 51: 255-260.

12. Earl JC, Mackney AW, The action of acetic anhydride on N-nitrosophenylglycine and some of its derivatives. J Chem Soc., 1935: 899-900.

13. Lazar V, Balotescu MC, Moldovan L, Alexandru V, Ditu LM, Bulai D, Cernat R, Comparative evaluation of qualitative and quantitative methods used in the study of antifungal and antibacterial activity of hydroalcoholic vegetal extracts. Rom Biotechnol Lett., 2005; 10: 2225-2232.
14. Lazăr V, Microbial adherence, Romanian Academy Ed., Bucharest, 2003; 17-58. (available in Romanian)

15. Pincus DH, Microbial identification using the bioMérieux Vitek ${ }^{\circledR} 2$ system. In: Miller MJ, editor. Encyclopaedia of Rapid Microbiological Methods., PDA, Baltimore, 2006; 2: 1-32, www.pda.org/bookstore.

16. Saviuc C, Grumezescu AM, Oprea E, Radulescu V, Dascalu L, Chifiriuc MC, Bucur M, Banu O, Lazar $\mathrm{V}$, Antifungal activity of some vegetal extracts on Candida biofilms developed on inert substratum. Biointerface Res Appl Chem., 2011; 1(1): 15-23.

17. Suciu N, Mihai Gh, Elian M, Stroescu E, Sydnones: Reaction of lithium phenylsydnone with phosgene. Tetrahedron, 1965; 21: 1369-1371. 